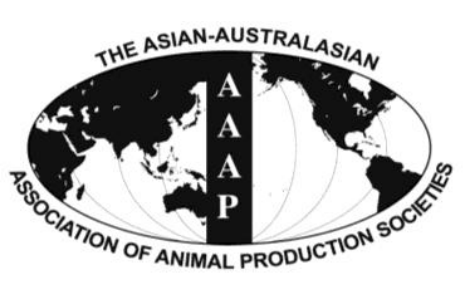

Open Access

Asian Australas. J. Anim. Sci.

Vol. 27, No. 1 : 46-54 January 2014

http://dx.doi.org/10.5713/ajas.2013.13301

www.ajas.info

pISSN 1011-2367 elSSN 1976-5517

\title{
Effects of Eucalyptus Crude Oils Supplementation on Rumen Fermentation, Microorganism and Nutrient Digestibility in Swamp Buffaloes
}

\author{
N. T. Thao ${ }^{1,2}$, M. Wanapat ${ }^{2} *$, A. Cherdthong ${ }^{2}$, and S. Kang ${ }^{2}$ \\ ${ }^{1}$ Department of Animal Science and Veterinary Medicine, An Giang University, An Giang, Vietnam
}

\begin{abstract}
This study was conducted to investigate the effects of eucalyptus (E. Camaldulensis) crude oils (EuO) supplementation on voluntary feed intake and rumen fermentation characteristics in swamp buffaloes. Four rumen fistulated swamp buffaloes, body weight (BW) of $420 \pm 15.0 \mathrm{~kg}$, were randomly assigned according to a $2 \times 2$ factorial arrangement in a $4 \times 4$ Latin square design. The dietary treatments were untreated rice straw (RS) without $\mathrm{EuO}(\mathrm{T} 1)$ and with $\mathrm{EuO}(\mathrm{T} 2)$ supplementation, and $3 \%$ urea-treated rice straw (UTRS) without EuO (T3) and with EuO (T4) supplementation. The EuO was supplemented at $2 \mathrm{~mL} / \mathrm{h} / \mathrm{d}$ in respective treatment. Experimental animals were kept in individual pens and concentrate mixture was offered at $3 \mathrm{~g} / \mathrm{kg} \mathrm{BW}$ while roughage was fed ad libitum. Total dry matter and roughage intake, and apparent digestibilites of organic matter and neutral detergent fiber were improved $(\mathrm{p}<0.01)$ by UTRS. There was no effect of EuO supplementation on feed intake and nutrient digestibility. Ruminal $\mathrm{pH}$ and temperature were not $(p>0.05)$ affected by either roughage sources or EuO supplementation. However, buffaloes fed UTRS had higher ruminal ammonia nitrogen and blood urea nitrogen as compared with RS. Total volatile fatty acid and butyrate proportion were similar among treatments, whereas acetate was decreased and propionate molar proportion was increased by EuO supplementation. Feeding UTRS resulted in lower acetate and higher propionate concentration compared to RS. Moreover, supplementation of EuO reduced methane production especially in UTRS treatment. Protozoa populations were reduced by EuO supplementation while fungi zoospores remained the same. Total, amylolytic and cellulolytic bacterial populations were increased $(p<0.01)$ by UTRS; However, EuO supplementation did not affect viable bacteria. Nitrogen intake and in feces were found higher in buffaloes fed UTRS. A positive nitrogen balance (absorption and retention) was in buffaloes fed UTRS. Supplementation of EuO did not affect nitrogen utilization. Both allantoin excretion and absorption and microbial nitrogen supply were increased by UTRS whereas efficiency of microbial protein synthesis was similar in all treatments. Findings of present study suggested that EuO could be used as a feed additive to modify the rumen fermentation in reducing methane production both in RS and UTRS. Feeding UTRS could improve feed intake and efficiency of rumen fermentation in swamp buffaloes. However, more research is warranted to determine the effect of EuO supplementation in production animals. (Key Words: Eucalyptus Oils, Rumen Fermentation, Nutrients Digestibility, Rice Straw, Swamp Buffalo)
\end{abstract}

\section{INTRODUCTION}

Mitigation of methane $\left(\mathrm{CH}_{4}\right)$ production in the tropics is important because more than half of the world's livestock population is raised in this area. Moreover, due to low

\footnotetext{
* Corresponding Author: M. Wanapat. Tel: +66-4320-2368, Fax: +66-4320-2368, E-mail: metha@kku.ac.th

${ }^{2}$ Tropical Feed Resources Research and Development Center, (TROFREC), Department of Animal Science, Faculty of Agriculture, Khon Kaen University, Khon Kaen 40002, Thailand. Submitted May 29, 2013; Accepted Sept. 26, 2013; Revised Nov. 1, 2013
}

quantity and quality of feedstuffs the feed requirement in the tropics tends to be higher for similar production than that in the subtropics. Feedstuffs in the tropics, especially rice straw, are characterized by high fiber and lignin, and low digestible fractions (Kebreab et al., 2012). Therefore, the animal needs more feed per unit of production, and emits higher $\mathrm{CH}_{4}$ levels because dry matter intake (DMI) is highly correlated with $\mathrm{CH}_{4}$ production (Shibata et al., 1993). Improving feed quality is one of the proven methods to reduce $\mathrm{CH}_{4}$ production (Leng, 1993). Swamp buffaloes are raised all over Asia and contribute directly to human 
nutrition and socio-economic welfare and to the productivity of mixed crop-livestock production systems, national resources management and the security of resource-poor farmers. Swamp buffaloes play a very important role in providing draught power, manure as fertilizer and meat for human consumption (Chantalakhana, 2001). Moreover, swamp buffaloes are considered potentially the most efficient ruminant due to their ability to utilize low quality tropical feedstuffs (Devendra, 1992).

Essential oils, which are extracted from plants by steam distillation, are known to have antimicrobial effects due to their ability to modify cell permeability in microbes (Helander et al., 1998). These substances have also been proposed to be modifiers of rumen fermentation due to their toxicity to some unfavorable strains of rumen bacteria, such as methanogens (Wallace, 2004). Eucalyptus oils (EuO) are also well known as a traditional medicine with several biological activities such as bacteriostatic, fungistatic, antiprotozoa, anti-inflammatory and could modify ruminal fermentation characteristic and $\mathrm{CH}_{4}$ mitigation (Sallam et al., 2009; Sallam et al., 2010). However, there is very little experimental evidence of the effects of $\mathrm{EuO}$ on rumen microbial fermentation and nutrient digestibility. Therefore, this study was undertaken to investigate the effects of $\mathrm{EuO}$ supplementation on feed intake rumen fermentation and nutrients digestibility in swamp buffaloes fed with untreated and urea treated rice straw.

\section{MATERIALS AND METHODS}

\section{Animals, diets and experimental design}

In brief, EuO extraction procedure was based on a water distillation process. Approximately $100 \mathrm{~kg}$ of Eucalyptus leaves were collected and put into $300 \mathrm{~L}$ steel barrel with $100 \mathrm{~L}$ of water. The barrel was then covered tightly with a lid which was connected with a pipe and cooling coil in a cooling device. At the end of cooling device, a plastic bottle was used for collecting aromatic fluid. The barrel was then boiled for approximately $5 \mathrm{~h}$, and essential oils were then collected by separating the oils floating on the aromatic fluid.

Four, ruminal fistulated swamp buffaloes with initial body weight $(\mathrm{BW})$ of $420 \pm 15.0 \mathrm{~kg}$, were randomly assigned to four dietary treatments according to a $2 \times 2$ factorial arrangement in a $4 \times 4$ Latin square design. The dietary treatments were as follow: untreated rice straw (RS) without $\mathrm{EuO}$ (T1) and with EuO (T2) supplementation, and 3\% urea-treated rice straw (UTRS) without EuO (T3) and with EuO supplementation (T4). The EuO was supplemented at $2 \mathrm{~mL} / \mathrm{hd} / \mathrm{d}$ and both RS and UTRS were fed ad libitum. Concentrate $(14.2 \% \mathrm{CP})$ was fed daily at $0.3 \% \mathrm{BW}$ twice daily at $07.00 \mathrm{~h}$ and $16.00 \mathrm{~h}$. All experimental animals were kept in individual pens with availability of clean fresh water and mineral blocks at all times. The experiment was conducted for 4 periods, and each period lasted for $21 \mathrm{~d}$. During the first $14 \mathrm{~d}$, DMI was recorded, while during the last $7 \mathrm{~d}$, all animal were moved to metabolism crates for total feces and urine collections.

\section{Data collection and sampling procedures}

Feed and fecal samples were collected by total collection from each individual buffalo during the last $7 \mathrm{~d}$ of each period at the morning and afternoon feeding, and a $10 \%$ sample was composited by buffalo and period, and then stored $\left(-20^{\circ} \mathrm{C}\right)$ until analysis. Samples were dried in a forced-air oven at $60^{\circ} \mathrm{C}$ for $96 \mathrm{~h}$ and ground through a 1-mm stainless steel screen (Cyclotec 1093 Sample mill, Tecator, Hoganas, Sweden), then analyzed for dry mater (DM) and organic matter (OM) according to the AOAC (1995). The crude protein (CP) content was determined by using a Kjeltec Auto 1030 Analyzer (Tecator). The method of Van Soest et al. (1991) was used to determine neutral detergent fiber (NDF) (amylase added) and acid detergent fiber (ADF) on an ash-free basis using an Ankom Fiber Analyzer incubator (Ankom Technology, Fairport, NY).

At the end of each period, a rumen fluid sample was collected immediately at $0,2,4,6 \mathrm{~h}$ post morning feeding on the last day of each period. Approximate $200 \mathrm{~mL}$ of rumen fluid was collected at each time from the different parts of the rumen using a $60 \mathrm{~mL}$ hand syringe. The $\mathrm{pH}$ and temperature of rumen fluid was measured immediately by a portable $\mathrm{pH}$ temperature meter (HANNA Instruments HI 8424 microcomputer, Singapore). Rumen fluid samples were then filtered through 4 layers of cheesecloth and divided into 3 portions. The first $45 \mathrm{~mL}$ of rumen fluid sample was collected and kept in a plastic bottle to which 5 $\mathrm{mL}$ of $1 \mathrm{M} \mathrm{H}_{2} \mathrm{SO}_{4}$ was added to stop the fermentation process due to microbial activity and then centrifuged at $3,000 \times g$ for $10 \mathrm{~min}$. About 20 to $30 \mathrm{~mL}$ of supernatant was collected and analyzed for $\mathrm{NH}_{3}-\mathrm{N}$ by Kjeltech Auto 1030 Analyzer (AOAC, 1995) and VFA using High Pressure Liquid Chromatography (HPLC, Instruments by Water and Novapak model 600E; water mode 1484 UV detector; column novapak C18; column size $3.9 \mathrm{~mm} \times 300 \mathrm{~mm}$; mobile phase $\left.10 \mathrm{mM} \mathrm{H}_{2} \mathrm{PO}_{4}[\mathrm{pH} 2.5]\right)$ according to Samuel et al. (1997). The second portion of $1 \mathrm{~mL}$ rumen fluid was collected and kept in a plastic bottle to which $9 \mathrm{~mL}$ of 10 $\mathrm{mL} / \mathrm{L}$ formalin solution $(1: 9 \mathrm{v} / \mathrm{v}$, rumen fluid: $10 \mathrm{~mL} / \mathrm{L}$ formalin) was added and stored at $4{ }^{\circ} \mathrm{C}$ for measuring protozoal populations by total direction counts using methods of Galyean (1989) by haemacytometer (Boeco, Singapore). The third portion was for the total viable bacteria count (cellulolytic, proteolytic, amylolytic and total viable bacteria) using the Hungate (1969) roll-tube technique. 
A blood sample (about $10 \mathrm{~mL}$ ) was collected from the jugular vein at the same time as rumen fluid sampling into tubes containing $12 \mathrm{mg}$ of EDTA and plasma was separated by centrifugation at $500 \times \mathrm{g}$ for $10 \mathrm{~min}$ at $4^{\circ} \mathrm{C}$ and stored at $-20^{\circ} \mathrm{C}$ until analysis for blood urea nitrogen (BUN) according to Crocker (1967). Calculation of ruminal methane $\left(\mathrm{CH}_{4}\right)$ production was based on VFA proportions according to Moss et al. (2000) as follows: $\mathrm{CH}_{4}$ production $=0.45$ (acetate) -0.275 (propionate $)+0.4$ (butyrate) .

Total urine excretion was collected and acidified using $10 \mathrm{~mL}$ of $\mathrm{H}_{2} \mathrm{SO}_{4}$ solution $(2 \mathrm{M})$. Urine samples were analyzed for total $\mathrm{N}$ (AOAC, 1995) to calculate for $\mathrm{N}$ balance and allantoin in urine was determined by HPLC as described by Chen et al. (1993). The amount of microbial purines derivative absorption was calculated from purine derivative (PD) excretion based on the relationship derived by the equation of Liang et al. (1994): $\mathrm{Y}=0.12 \mathrm{X}+(0.20$ $\left.\mathrm{BW}^{0.75}\right)$. The supply of microbial $\mathrm{N}(\mathrm{MN})$ was estimated by urinary excretion of $\mathrm{PD}$ according to Chen and Gomes (1995): $\mathrm{MN}(\mathrm{g} / \mathrm{d})=70 \mathrm{X} /(0.116 \times 0.83 \times 1,000)=0.727 \mathrm{X}$; where $\mathrm{X}$ and $\mathrm{Y}$ are, respectively, absorption and excretion of PD in mmol/d. Efficiency of microbial $\mathrm{N}$ synthesis (EMNS) was calculated using the following formula: EMNS = microbial $\mathrm{N}(\mathrm{g} / \mathrm{d}) / \mathrm{DOMR}$; where $\mathrm{DOMR}=$ digestible $\mathrm{OM}$ apparently fermented in the rumen (assuming that rumen digestion was $650 \mathrm{~g} / \mathrm{kg} \mathrm{OM}$ of digestion in total tract, $\mathrm{DOMR}=\mathrm{DOMI} \times 0.65 ; \mathrm{DOMI}=$ digestible organic matter intake).

\section{Statistical analysis}

All data obtained from the experiment were subjected to ANOVA for a $4 \times 4$ Latin square design with $2 \times 2$ factorial arrangements of treatments using the General Linear Models (GLM) procedures of the Statistical Analysis System Institute (SAS, 1998). The statistical model included terms for animal, period, roughage sources, EuO and the roughage sources $\times \mathrm{EuO}$ interactions. Treatment means were compared by Tukey's Multiple Comparison Test (Crichton, 1999).

\section{RESULTS}

\section{Chemical composition of diet}

Experimental feeds and their chemical compositions are presented in Table 1. The mixture concentrates consisted of cassava chip, rice bran, coconut meal, palm meal, molasses, sulfur and minerals and had high quality in terms of high $\mathrm{CP}$ and low fiber fraction. Rice straw had low $\mathrm{CP}$ and high $\mathrm{NDF}$ and ADF content; however, the quality of rice straw was improved by urea treatment at $3 \%$ in increasing $\mathrm{CP}$ and reducing fiber content.
Table 1. Ingredients and chemical compositions of concentrate, rice straw and urea treated rice straw

\begin{tabular}{|c|c|c|c|}
\hline$\overline{\text { Items }}$ & Concentrate & $\mathrm{RS}$ & UTRS \\
\hline \multicolumn{4}{|l|}{ Ingredients (\% dry matter) } \\
\hline Cassava chip & 65.0 & & \\
\hline Rice bran & 10.0 & & \\
\hline Palm meal & 20.2 & & \\
\hline Urea & 1.5 & & \\
\hline Molasses & 1.5 & & \\
\hline Sulfur & 0.3 & & \\
\hline Premix mineral $^{\mathrm{a}}$ & 1.0 & & \\
\hline Salt & 0.5 & & \\
\hline \multicolumn{4}{|l|}{ Chemical composition (\%) } \\
\hline \multirow[t]{2}{*}{ Dry matter } & 93.2 & 91.6 & 53.5 \\
\hline & . & dry $n$ & \\
\hline Organic matter & 94.7 & 87.5 & 88.2 \\
\hline Ash & 5.3 & 12.5 & 11.8 \\
\hline Crude protein & 14.2 & 2.5 & 5.4 \\
\hline Neutral detergent fiber & 16.0 & 76.2 & 74.3 \\
\hline Acid detergent fiber & 8.4 & 53.8 & 57.8 \\
\hline
\end{tabular}

RS = Rice straw; UTRS $=3 \%$ urea-treated rice straw.

${ }^{a}$ Minerals and vitamins (each $\mathrm{kg}$ contain): vitamin A 10,000,000 IU; vitamin E 70,000 IU; Vitamin D 1,600,000 IU; Fe 50 g; Zn 40 g; Mn 40 g; Co $0.1 \mathrm{~g}$; Se $0.1 \mathrm{~g}$; I $0.5 \mathrm{~g}$.

\section{Feed intake and nutrient digestibility}

Supplementing swamp buffaloes with EuO had no effect on DM intake (Table 2) but urea treatment increased $(\mathrm{p}<0.01)$ straw intake. Apparent digestibility of OM and NDF were also found to have increased $(p<0.001)$ in buffaloes fed UTRS diets. However, EuO supplementation did not changed nutrient digestibility.

\section{Rumen fermentation and blood metabolites}

As shown in Table 3, rumen temperature and $\mathrm{pH}$ were similar among treatments and values were quite stable. Buffaloes fed with UTRS had higher concentration of ruminal $\mathrm{NH}_{3}-\mathrm{N}$ and BUN as compared to RS. However, EuO supplementation did not affect on ruminal $\mathrm{NH}_{3}-\mathrm{N}$ and BUN concentrate. There were no differences in total volatile fatty acid (TVFA) and butyrate $\left(\mathrm{C}_{4}\right)$ concentration among treatments by roughage source or $\mathrm{EuO}$ supplementation. Roughage sources and $\mathrm{EuO}$ supplementation influenced acetate $\left(\mathrm{C}_{2}\right)$ and propionate $\left(\mathrm{C}_{3}\right)$ concentrations and $\mathrm{CH}_{4}$ production. The treatments with UTRS resulted in lower $\mathrm{C}_{2}$, but higher $\mathrm{C}_{3}$ as compared to RS. EuO supplementation reduced $\mathrm{C}_{2}$ and increased $\mathrm{C}_{3}$ concentration in both RS and UTRS. Production of $\mathrm{CH}_{4}$ was reduced by $\mathrm{EuO}$ supplementation especially in buffaloes fed UTRS.

\section{Rumen microorganism population}

The pprotozoa population was strongly inhibited by EuO supplementation, but not by roughage source, while 
Table 2. Effects of roughage source and Eucalyptus crude oil supplementation on voluntary feed intake and nutrients digestibility

\begin{tabular}{|c|c|c|c|c|c|c|c|c|}
\hline \multirow{2}{*}{ Items } & \multicolumn{2}{|c|}{$\mathrm{RS}$} & \multicolumn{2}{|c|}{ UTRS } & \multirow{2}{*}{ SEM } & \multicolumn{3}{|c|}{ Contrasts } \\
\hline & $-\mathrm{EuO}$ & $+\mathrm{EuO}$ & $-\mathrm{EuO}$ & $+\mathrm{EuO}$ & & $\mathrm{R}$ & $\mathrm{EuO}$ & $\mathrm{R} \times \mathrm{EuO}$ \\
\hline \multicolumn{9}{|c|}{ Feed intake (dry mater) } \\
\hline \multicolumn{9}{|l|}{ Total } \\
\hline $\mathrm{kg} / \mathrm{d}$ & $6.1^{\mathrm{a}}$ & $5.8^{\mathrm{a}}$ & $8.7^{\mathrm{b}}$ & $8.5^{\mathrm{b}}$ & 0.26 & $* *$ & ns & ns \\
\hline$\% \mathrm{BW}$ & $1.5^{\mathrm{a}}$ & $1.4^{\mathrm{a}}$ & $2.1^{\mathrm{b}}$ & $2.0^{\mathrm{b}}$ & 0.23 & $* *$ & ns & ns \\
\hline \multicolumn{9}{|l|}{ Roughage } \\
\hline $\mathrm{kg} / \mathrm{d}$ & $5.1^{\mathrm{a}}$ & $4.8^{\mathrm{a}}$ & $7.7^{\mathrm{b}}$ & $7.6^{\mathrm{b}}$ & 0.27 & $* *$ & ns & ns \\
\hline \multicolumn{9}{|c|}{ Concentrate } \\
\hline $\mathrm{kg} / \mathrm{d}$ & 1.0 & 1.0 & 1.0 & 0.9 & 0.05 & ns & ns & ns \\
\hline \multicolumn{9}{|c|}{ Apparent digestibility (\%) } \\
\hline $\mathrm{DM}$ & 59.1 & 60.0 & 63.6 & 65.5 & 2.45 & ns & ns & ns \\
\hline $\mathrm{OM}$ & $61.5^{\mathrm{a}}$ & $63.2^{\mathrm{ab}}$ & $66.6^{\mathrm{b}}$ & $67.3^{\mathrm{b}}$ & 1.74 & $* *$ & ns & ns \\
\hline $\mathrm{CP}$ & 51.0 & 54.5 & 56.2 & 56.6 & 4.16 & ns & ns & ns \\
\hline $\mathrm{NDF}$ & $55.1^{\mathrm{a}}$ & $60.1^{\mathrm{ab}}$ & $64.1^{\mathrm{bc}}$ & $67.4^{\mathrm{c}}$ & 1.94 & $* *$ & ns & 0.07 \\
\hline $\mathrm{ADF}$ & 47.5 & 49.2 & 52.6 & 51.6 & 2.88 & ns & ns & ns \\
\hline
\end{tabular}

RS = Rice straw; UTRS $=3 \%$ urea-treated rice straw; $\mathrm{R}=$ Roughage source; EuO = Eucalyptus crude oil supplementation at $2 \mathrm{~mL} / \mathrm{hd} / \mathrm{d}$.

ns = Non-significant; SEM = Standard error of mean.

$\mathrm{DM}=$ Dry matter; $\mathrm{OM}=$ Organic matter $\mathrm{CP}=$ Crude protein $\mathrm{NDF}=$ Neutral detergent fiber; $\mathrm{ADF}=$ Acid detergent fiber

$\mathbf{a}, \mathbf{b}, \mathbf{c}$ Values in the same row with different superscripts differ. ${ }^{*} * \mathrm{p}<0.01$.

the fungal zoospore population was similar in all treatments (Table 4). Total viable, amylolytic and cellulolytic bacteria counts were higher $(\mathrm{p}<0.001)$ in treatments with UTRS fed buffaloes whereas the population of proteolytic bacteria did not change by straw treatment or EuO supplementation. EuO supplementation did not affect the bacterial population in swamp buffaloes fed RS or UTRS.

\section{Nitrogen utilization, purine derivative and efficiency of microbial protein synthesis}

Total nitrogen intake and its excretion in feces and urine was higher in UTRS treatment (Table 5). However, EuO supplementation in diet did not affect nitrogen utilization in swamp buffaloes. Allantoin excretion and absorption, and microbial nitrogen supply (MNS) were increased by roughage treatment but $\mathrm{EuO}$ supplementation did not influence these attributes. Neither roughage treatment nor EuO supplementation changed efficiency of microbial nitrogen synthesis (EMNS) in buffaloes.

\section{DISCUSSION}

\section{Feed intake and nutrient digestibility}

There was no interaction between EuO supplementation and roughage sources on feed intake and nutrient digestibility in the present study. Total DMI and roughage intake were increased by UTRS, but not by EuO supplementation. However, it has been reported that there

Table 3. Effect of roughage source and Eucalyptus crude oils on rumen fermentation and blood metabolites

\begin{tabular}{|c|c|c|c|c|c|c|c|c|}
\hline \multirow{2}{*}{ Items } & \multicolumn{2}{|c|}{$\mathrm{RS}$} & \multicolumn{2}{|c|}{ UTRS } & \multirow{2}{*}{ SEM } & \multicolumn{3}{|c|}{ Contrasts } \\
\hline & $-\mathrm{EuO}$ & $+\mathrm{EuO}$ & $-\mathrm{EuO}$ & $+\mathrm{EuO}$ & & $\mathrm{R}$ & $\mathrm{EuO}$ & $\mathrm{R} \times \mathrm{EuO}$ \\
\hline Ruminal temp. $\left({ }^{\circ} \mathrm{C}\right)$ & 38.6 & 38.6 & 39.5 & 39.1 & 0.26 & ns & ns & ns \\
\hline Ruminal pH & 6.3 & 6.3 & 6.0 & 6.2 & 0.10 & ns & ns & ns \\
\hline $\mathrm{NH}_{3}-\mathrm{N}(\mathrm{mg} / \mathrm{dL})$ & $11.9^{\mathrm{a}}$ & $10.7^{\mathrm{a}}$ & $16.8^{\mathrm{b}}$ & $19.4^{\mathrm{b}}$ & 2.43 & $* *$ & ns & ns \\
\hline BUN (mg/dL) & $8.1^{\mathrm{a}}$ & $8.4^{\mathrm{a}}$ & $13.6^{\mathrm{b}}$ & $17.6^{\mathrm{b}}$ & 1.64 & $* *$ & ns & ns \\
\hline Total VFA (mM/L) & 133.9 & 135.8 & 129.4 & 134.4 & 5.07 & ns & ns & ns \\
\hline Acetate & $72.4^{\mathrm{a}}$ & $69.2^{\mathrm{b}}$ & $68.7^{\mathrm{b}}$ & $62.7^{\mathrm{c}}$ & 1.13 & $* *$ & $* *$ & ns \\
\hline Propionate & $15.4^{\mathrm{a}}$ & $18.9^{\mathrm{b}}$ & $19.2^{\mathrm{b}}$ & $23.8^{\mathrm{c}}$ & 0.04 & $* *$ & $* *$ & ns \\
\hline Butyrate & 12.2 & 11.8 & 12.1 & 13.4 & 0.45 & ns & ns & ns \\
\hline Methane $^{1}(\mathrm{~mol} / 100 \mathrm{~mol})$ & $33.2^{\mathrm{a}}$ & $30.1^{b}$ & $30.4^{\mathrm{b}}$ & $27.0^{\mathrm{c}}$ & 0.85 & $* *$ & $* *$ & ns \\
\hline
\end{tabular}

RS = Rice straw; UTRS $=3 \%$ urea-treated rice straw; R = Roughage source; EuO = Eucalyptus crude oil supplementation at $2 \mathrm{~mL} / \mathrm{hd} / \mathrm{d}$.

$\mathrm{NH}_{3}-\mathrm{N}=$ Ammonia nitrogen; $\mathrm{BUN}=$ Blood urea nitrogen; VFA = Volatile fatty acid.

$\mathrm{ns}=$ Non-significant SEM $=$ Standard error of mean .

a, b, c Values in the same row with different superscripts differ. $* \mathrm{p}<0.05 ; * * \mathrm{p}<0.01$.

${ }^{1}$ Calculated: $\mathrm{CH}_{4}=(0.45 \times$ acetate $)-(0.275 \times$ propionate $)+(0.40 \times$ butyrate $)$ based on Moss et al. $(2000)$. 
Table 4. Effects of roughage sources and Eucalyptus oils supplementation on microbial population

\begin{tabular}{|c|c|c|c|c|c|c|c|c|}
\hline \multirow{2}{*}{ Items } & \multicolumn{2}{|c|}{$\mathrm{RS}$} & \multicolumn{2}{|c|}{ UTRS } & \multirow{2}{*}{ SEM } & \multicolumn{3}{|c|}{ Contrasts } \\
\hline & $-\mathrm{EuO}$ & $+\mathrm{EuO}$ & $-\mathrm{EuO}$ & $+\mathrm{EuO}$ & & $\mathrm{R}$ & $\mathrm{EuO}$ & $\mathrm{R} \times \mathrm{EuO}$ \\
\hline \multicolumn{9}{|c|}{ Ruminal microbes (cell/mL) } \\
\hline Protozoa $\left(\times 10^{5}\right)$ & $7.3^{\mathrm{a}}$ & $5.8^{\mathrm{b}}$ & $8.7^{\mathrm{a}}$ & $6.9^{\mathrm{b}}$ & 0.47 & $\mathrm{~ns}$ & $* *$ & ns \\
\hline Fungi $\left(\times 10^{5}\right)$ & 3.8 & 2.9 & 3.6 & 3.2 & 0.35 & $\mathrm{~ns}$ & ns & ns \\
\hline \multicolumn{9}{|c|}{ Viable bacteria $(\mathrm{cfu} / \mathrm{mL})$} \\
\hline Total $\left(\times 10^{9}\right)$ & $1.9^{\mathrm{a}}$ & $2.4^{\mathrm{a}}$ & $4.0^{\mathrm{b}}$ & $2.3^{\mathrm{a}}$ & 0.45 & 0.07 & ns & $*$ \\
\hline Proteolytic $\left(\times 10^{7}\right)$ & 1.8 & 2.1 & 2.3 & 2.7 & 0.63 & 0.09 & ns & ns \\
\hline Amylolytic $\left(\times 10^{7}\right)$ & $2.9^{\mathrm{a}}$ & $1.9^{\mathrm{a}}$ & $3.5^{\mathrm{b}}$ & $4.7^{\mathrm{b}}$ & 0.57 & $* *$ & ns & ns \\
\hline Cellulolytic $\left(\times 10^{8}\right)$ & $1.7^{\mathrm{a}}$ & $2.1^{\mathrm{a}}$ & $5.4^{\mathrm{b}}$ & $4.4^{\mathrm{b}}$ & 0.52 & $* *$ & ns & $\mathrm{ns}$ \\
\hline
\end{tabular}

RS = Rice straw; UTRS = 3\% urea-treated rice straw; $\mathrm{R}=$ Roughage source; EuO = Eucalyptus crude oil supplementation at $2 \mathrm{~mL} / \mathrm{hd} / \mathrm{d}$.

a, b, c Values in the same row with different superscripts differ. $* \mathrm{p}<0.05 ; * * \mathrm{p}<0.01$.

are variable observations on feed intake depending on the type of essential oil (EO) and dose (Cardozo et al., 2006). Feeding $250 \mathrm{mg} / \mathrm{d}$ of oregano plants EO in sheep (Wang et al., 2009), 2 g/d of juniper berry EO in cows (Yang et al., 2007), 0.75 or $2 \mathrm{~g}$ of EO mixture in dairy cattle (Benchaar et al., 2006a, 2007) and 0.043 or $0.43 \mathrm{~g} / \mathrm{kg}$ feed intake in dairy goats (Malecky et al., 2009) did not influence on feed intake. On the other hand, Busquest et al. (2003) reported that high dose of cinnamadehyde $(500 \mathrm{mg} / \mathrm{d})$ in dairy cattle adversely affected on feed intake. In contrast, Yang et al. (2010) clearly demonstrated that cinnamaldehyde had a greater feed intake response at low dose $(0.4 \mathrm{~g} / \mathrm{d})$, whereas a higher dose at $1.6 \mathrm{~g} / \mathrm{d}$ had no effect on intake of steers. Under the present study, buffaloes fed with UTRS had greater feed intake and digestibility of OM and NDF as compared with those fed with RS. This result agreed with Wanapat et al. (1985) who reported that urea-treatment could increase overall feed intake and nutrient digestibility of straw. It was also reported that urea could provide a source of CP which is deficient in straw (Preston and Leng, 1987). Moreover, in the process of treating rice straw, the concentrated alkaline agents in form of ammonium hydroxide can chemically break the ester bonds between lignin, hemicelluloses and cellulose, and physically make structural fibers swollen. These effects enable rumen microbes to attack the structural carbohydrates more easily, hence higher intake and degradability could be obtained (Fadel Elseed et al., 2003). However, apparent digestibilities of DM, OM, CP, NDF and ADF were not influenced by EuO supplementation, which agreed with the results of Benchaar et al. (2006b, 2007) and Santos et al. (2004), who reported no changes in apparent total tract digestibility in dairy cows fed with $2 \mathrm{~g} / \mathrm{d}$ of mixture EO.

\section{Rumen fermentation and blood metabolites}

There were no effects of EuO supplementation and roughage sources on ruminal $\mathrm{pH}$ and temperature $(\mathrm{p}>0.05)$. Ruminal $\mathrm{pH}$ and temperature in the present study were in

Table 5. Effects of roughage source and Eucalyptus crude oils supplementation on nitrogen metabolism and microbial protein synthesis

\begin{tabular}{|c|c|c|c|c|c|c|c|c|}
\hline \multirow{2}{*}{ Items } & \multicolumn{2}{|c|}{$\mathrm{RS}$} & \multicolumn{2}{|c|}{ UTRS } & \multirow{2}{*}{ SEM } & \multicolumn{3}{|c|}{ Contrast } \\
\hline & $-\mathrm{EuO}$ & $+\mathrm{EuO}$ & $\mathrm{EuO}$ & $+\mathrm{EuO}$ & & $\mathrm{R}$ & $\mathrm{EuO}$ & $\mathrm{R} \times \mathrm{EuO}$ \\
\hline \multicolumn{9}{|l|}{$\overline{\mathrm{N} \text { utilization }(\mathrm{g} / \mathrm{d})}$} \\
\hline Intake & $42.1^{\mathrm{a}}$ & $43.2^{\mathrm{a}}$ & $89.0^{\mathrm{b}}$ & $88.8^{\mathrm{b}}$ & 0.70 & $* *$ & ns & ns \\
\hline \multicolumn{9}{|l|}{ Excretion } \\
\hline Feces & $21.2^{\mathrm{a}}$ & $20.2^{\mathrm{a}}$ & $38.0^{\mathrm{b}}$ & $38.6^{\mathrm{b}}$ & 0.55 & $* *$ & ns & ns \\
\hline Urine & 9.1 & 7.5 & 11.2 & 13.1 & 1.62 & 0.05 & ns & ns \\
\hline \multicolumn{9}{|l|}{ Balance } \\
\hline Absorption & $20.9^{\mathrm{a}}$ & $23.0^{\mathrm{a}}$ & $51.0^{\mathrm{b}}$ & $50.2^{\mathrm{b}}$ & 1.53 & $* *$ & ns & ns \\
\hline Retention & $13.0^{\mathrm{a}}$ & $16.4^{\mathrm{a}}$ & $38.8^{\mathrm{b}}$ & $37.2^{\mathrm{b}}$ & 1.55 & $* *$ & ns & ns \\
\hline \multicolumn{9}{|l|}{ Purine derivative (mmol/d) } \\
\hline Allantoin excretion & $22.9^{\mathrm{a}}$ & $22.7^{\mathrm{a}}$ & $26.2^{\mathrm{b}}$ & $28.4^{\mathrm{b}}$ & 1.32 & $* *$ & ns & ns \\
\hline Allantoin absorption & $66.5^{\mathrm{a}}$ & $66.9^{\mathrm{a}}$ & $94.5^{\mathrm{b}}$ & $114.2^{\mathrm{b}}$ & 5.18 & $* *$ & ns & ns \\
\hline MNS (gN/d) & $48.7^{\mathrm{a}}$ & $48.7^{\mathrm{a}}$ & $68.7^{\mathrm{b}}$ & $83.0^{\mathrm{b}}$ & 3.78 & $*$ & ns & ns \\
\hline EMPS (gN/kg OMDR) & 27.3 & 28.5 & 24.3 & 29.4 & 1.93 & ns & ns & ns \\
\hline
\end{tabular}

RS = Rice straw; UTRS = 3\% urea-treated rice straw; R = Roughage source; EuO = Eucalyptus crude oil supplementation at $2 \mathrm{~mL} / \mathrm{hd} / \mathrm{d}$.

MNS = Microbial nitrogen supply; EMPS = Efficiency of microbial nitrogen synthesis; OMDR = Digestible organic matter apparently fermented in the rumen.

${ }^{\mathrm{a}, \mathrm{b}}$ Values in the same row with different superscripts differ. $* \mathrm{p}<0.05 ; * * \mathrm{p}<0.01$ 
normal range at $38.6^{\circ} \mathrm{C}$ to $39.5^{\circ} \mathrm{C}$ and $6.0-6.3$, respectively, as reported by Wanapat (1990). Yang et al. (2007) who used garlic $(5 \mathrm{~g} / \mathrm{d})$ and juniper berry $(2 \mathrm{~g} / \mathrm{d})$ EO in lactating cows found that there was no effect of $\mathrm{EO}$ on ruminal $\mathrm{pH}$. In addition, Chaves et al. (2008a) also reported that no change in ruminal $\mathrm{pH}$ when growing lambs were supplemented with cinnamaldehyde, garlic and juniper berry EO.

Supplementation of EuO did not affect on ruminal $\mathrm{NH}_{3^{-}}$ $\mathrm{N}$ and BUN in this study. Buquest et al. (2006), who conducted in vitro studies, reported that addition of anethol (3,000 mg/L), carvacrol and carvone (300 mg/L) had no effect on $\mathrm{NH}_{3}-\mathrm{N}$ concentration. Indeed, Benchaar et al. (2006b, 2007) observed no change in ruminal $\mathrm{NH}_{3}-\mathrm{N}$ concentration, when lactating dairy cows were supplemented with EO at doses of 0.75 or $2 \mathrm{~g} / \mathrm{d}$. McIntosh et al. (2003) demonstrated that EO inhibited growth of some (i.e., Clostridium sticklandii and Peptostreptococcus anaerobius) hyper-ammonia producing (HAP) bacteria, but other HAP bacteria (e.g., Clostridium aminophilum) were less sensitive. Hyper-ammonia producing bacteria are present in low numbers in the rumen $(<0.01$ of the rumen bacterial population), but they possess a very high deamination activity (Russell et al., 1988). Wallace (2004) reported that the number of HAP bacteria was reduced by $77 \%$ in sheep receiving a low protein diet supplemented with EO at $100 \mathrm{mg} / \mathrm{d}$, but that EO had no effect on HAP bacteria when sheep were fed a high-protein diet. On the other hand, $\mathrm{NH}_{3}-\mathrm{N}$ and BUN were higher in buffaloes fed with UTRS as compared with RS. This could be a consequent result from having a higher nitrogen intake contributed by UTRS. Similarly, Hess et al. (2000) found that ruminal $\mathrm{NH}_{3}-\mathrm{N}$ concentration was linearly correlated with the level of dietary CP $\left(p<0.001, r^{2}=0.77-0.92\right)$. According to numerous reports, the optimal level of ruminal ammonia concentration for efficient digestion ranged from 5.0 to $25.0 \mathrm{mg} / \mathrm{dL}$ (Preston and Leng, 1987) and 15 to 30 mg/dL (Perdok and Leng, 1989; Wanapat and Pimpa, 1999). Bunting et al. (1987) reported that BUN levels reflected the protein status of cattle and positively corresponded to the change in $\mathrm{NH}_{3}-\mathrm{N}$ concentration in rumen fluid.

Under this current study, no effects of both $\mathrm{EuO}$ supplementation and type of rice straw were found on total VFA production and $\mathrm{C}_{4}$ concentration. These results agreed with Newbold et al. (2004) and Beauchamin and Mc Ginn (2006) who observed no changes in total VFA production when EO was fed to sheep or cattle. Indeed, Busquest et al. (2006), who studied the effects of various plant extracts and secondary plant metabolites on ruminant fermentation in a $24 \mathrm{~h}$ batch culture, where each treatment was supplied at varying dose up to $3 \mathrm{~g} / \mathrm{L}$ of culture fluid, found that none of the EO or EO compounds could increase total VFA concentration; although they decreased VFA concentration at the highest concentration. The lack of $\mathrm{EuO}$ supplement effect on molar proportion of $\mathrm{C}_{4}$ is consistent with the results obtained from dairy cows supplemented with a mixture of EO in the study of Benchaar et al. (2006a; 2007). Meanwhile, Eucalyptus oils addition reduced $\mathrm{C}_{2}$ proportion and increased $\mathrm{C}_{3}$ proportion. This result agreed with Agarwal et al. (2009) who reported that peppermint oils addition to buffaloes rumen liquor resulted in decreasing $\mathrm{C}_{2}$ and increasing $\mathrm{C}_{3}$. Another in vitro study conducted by Buquest et al. (2005), using garlic oils, found results similar to the previous report. In the present results, $\mathrm{EuO}$ supplementation caused a reduction of $\mathrm{C}_{2}: \mathrm{C}_{3}$ ratio and this was consistent to several works in vivo of Cardozo et al. (2006), Wanapat et al. (2008) and Giannenas et al. (2011). The present study showed that feeding UTRS resulted in reducing $\mathrm{C}_{2}$ and increasing $\mathrm{C}_{3}$ proportions in the rumen as compared to RS. This result was similar with the studies by Wanapat et al. (2009) who reported that urea treatment of straw could alter VFA proportion concentration in the rumen. These results could be due to the treatment of straw with urea that would result in increased availability of carbohydrate for degradation by the rumen microorganisms; hence, lead to the improvement of digestibility rate. Thereby, it could lead to the decrease of molar proportion of $\mathrm{C}_{2}$ and increase that of $\mathrm{C}_{3}$.

The inhibition of $\mathrm{CH} 4$ production in the rumen by specifically targeting the methanogens is usually associated with a decrease in $\mathrm{C}_{2}$ to $\mathrm{C}_{3}$ ratio (Patra, 2011). Results in present study showed that $\mathrm{CH}_{4}$ production calculated by the equation of Moss et al. (2000) was approximately $8 \%$ lower in EuO treatments compared to non supplemented treatments. This result was in agreement with several previous studies on inhibitory properties of EO both in vitro and in vivo. For instance, juniper berry EO and cinnamol oil (Chaves et al., 2008b) and peppermint oil (Tatsouka et al., 2008; Agarwal et al., 2009) have been reported to have strong inhibitory effect on methanogennesis in vitro study. Furthermore, the in vivo study of Wang et al. (2009) showed that inclusion of EO from oregano plants in the diet could reduce $\mathrm{CH}_{4}$ profusion in sheep. In addition, Mohammed et al. (2004) observed that encapsulated horseradish EO decreased $\mathrm{CH}_{4}$ production by $19 \%$ in steers. Moreover, data in the present study showed that the total direct count of protozoa population (Table 4) in treatments with inclusion of $\mathrm{EuO}$ was lower than that in treatment without $\mathrm{EuO}$ supplementation and this could be the explanation for the decreasing $\mathrm{CH}_{4}$ production since ruminal protozoa provide a habitat for methanogens that live on and within them.

\section{Rumen microorganism population}

Total fungal zoospores, total viable, cellulolytic, proteolytic, and amylolytic bacteria populations were not 
affected by EuO supplementation in the diet. In agreement with this finding, Wallace et al. (2002) and Benchaar et al. (2007) reported that no changes in bacteria count was found when sheep and dairy cows were fed with mixed EO, respectively. However, the protozoa population was reduced by EuO addition in this study. Similarity, Ando et al. (2003) reported that feeding $200 \mathrm{~g} / \mathrm{d}$ peppermint to Holstein steers decreased the total number of protozoa which was attributed to the present of EO. It also has been observed that clove extract containing EO decreased total number of protozoa (Patra et al., 2010). More recently, Wanapat et al. (2008); Kongmun et al. (2010) Kongmun et al. (2011) reported that supplementation of garlic powder resulted in lower protozoa numbers in beef cattle and buffalo. In contrast, feeding UTRS significantly increased $(p<0.01)$ microbe growth in buffaloes as compared to RS feeding. These results were in agreement with the studies by Wanapat et al. (2009) and Khejornsart et al. (2011) who found that population of cellulolytic bacteria was increased by urea treated rice straw. Goto et al. (1993) reported that alkaline treatment partially damages the lignin - polysaccharide bond that solublizes hemicelluloses and lignin in straw, and hence exposes the cellulose to microbial attack. Moreover, Chen et al. (2008) reported that chemical treatment enhanced the nutritive value of rice straw through increasing the number of accessible sites of microbial attachment on the surface of particles, increasing fibrolytic microbe quantity and hence fibrolytic enzyme activities, and improving rumen fermentation characteristics.

\section{Nitrogen utilization and microbial protein synthesis}

Inclusion of EuO in the treatments dietary did not affect nitrogen utilization and microbial protein synthesis in the present study. Benchaar et al. (2006a,b; 2007) observed that there was no change in nitrogen retention and duodenal bacteria flow (estimate from urinary purine derivative) when cows were fed with EO. In addition, Tekipper et al. (2010) reported that supplementation of $500 \mathrm{~g}$ of origanum vulgare leaves in lactating dairy cows had no effect on urinary and fecal loss as well as urinary purine derivative and microbial protein synthesis. Nitrogen retention and microbial protein synthesis estimated using purine derivative was higher in urea-treated rice straw diet. This result agreed with Pradan et al. (1996) who reported that N retention was increased by urea or ammonia treated rice straw when compared with untreated rice straw. Under this study, allantoin excretion and allantoin absorption were increased $(p<0.001)$ in the buffaloes fed with urea-treated rice straw. In addition, Hoover and Stokes (1991) reported that the rate of digestion of carbohydrates was a major factor controlling the energy available for microbial growth. As discussed above, urea treatment of rice straw could break-down the physical form of rice straw, hence resulted in higher digestibility of $\mathrm{OM}$ with the consequence of improving the rate of digestion. Moreover, urea as ammonium or ammonium carbonate in urea-treated rice straw could provide nitrogen source for microbes for a more rapid colonization on the surface of roughage in the rumen.

\section{CONCLUSION}

In summary, feeding UTRS could enhance feed intake, nutrient digestibility and efficiency of rumen fermentation of swamp buffaloes. Moreover, supplementation EuO at 2 $\mathrm{mL} / \mathrm{hd} / \mathrm{d}$ did not show any negative effect on feed intake and rumen fermentation; however, it could reduce protozoa population and methane production. Therefore, it could be concluded that EuO could be used to manipulate rumen fermentation in swamp buffaloes as potential feed additive to improve rumen fermentation, mitigation methane production without negative effect on feed intake, nutrient digestibility and rumen fermentation.

\section{ACKNOWLEDGEMENTS}

Tropical Feed Resources Research and Development Center (TROFREC), Department of Animal Science, Faculty of Agriculture, Khon Kaen University, Thailand and the Vietnam International Education Development (VIED), Ministry of Education and Training, Vietnam are gratefully acknowledged for the use of research facilities and financial support.

\section{REFERENCES}

Agarwal, N., C. Shekhar, R. Kumar, L. C. Chaudhary, and D. N. Kamra. 2009. Effect of peppermint (Mentha piperita) oil on in vitro methanogenesis and fermentation of feed with buffalo rumen liquor. Anim. Feed Sci. Technol. 148:321-327.

Ando, S., T. Nishida, M. Ishida, K. Hosoda, and E. Bayaru. 2003. Effect of peppermint feeding on the digestibility, ruminant fermentation and protozoa. Livest. Prod. Sci. 82:245-248.

AOAC. 1995. Official methods of analyses, 16th ed. Animal Feeds: Association of Official Analytical Chemists, VA, USA.

Beauchemin, K. A. and S. N. McGinn. 2006. Methane emissions from beef cattle: effects of fumaric acid, essential oil, and canola oil. J. Anim. Sci. 84:1489-1496.

Benchaar, C., H. V. Petit, R. Berthiaume, T. D. Whyte, and P. Y. Chouinard. 2006a. Effects of addition of essential oils and monensin premix on digestion, ruminal fermentation, milk production and milk composition in dairy cows. J. Dairy Sci. 89:4352-4364.

Benchaar, C., J. L. Duynisveld, and E. Charmley. 2006b. Effects of monensin and increasing dose levels of a mixture of essential oil compounds on intake, digestion and growth performance of beef cattle. Can. J. Anim. Sci. 86:91-96.

Bencharr, C., H. V. Petit, R. Berthiaume, D. R. Ouellet, J. Chiquette, and P. Y. Chouinard. 2007. Effects of essential oils on digestion, ruminal fermentation, rumen microbial 
populations, milk production, and milk composition in dairy cows fed alfalfa silage or corn silage. J. Dairy. Sci. 90:886-897.

Bunting, L. D., J. A. Boling, C. T. MacKown, and R. B. Muntifering. 1987. Effect of dietary protein level on nitrogen metabolism in lambs: Studies using $15 \mathrm{~N}$-nitrogen. J. Anim. Sci. 64:855-867.

Busquet, M., S. Calsamiglia, A. Ferret, and C. Kamel. 2003. Efecto del extracto de ajo y/o cinnamaldehí do sobre la producción, composición y residuos en vacas de alta producción. ITEA Vol-Extra. 24:756-758.

Busquet, M., S. Calsamiglia, A. Ferret, and C. Kamel. 2006. Plant extracts affect in vitro rumen microbial fermentation. J. Dairy Sci. 89:761-771.

Busquet, M., S. Calsamiglia, A. Ferret, M. D. Carro, and C. Kamel. 2005. Effects of garlic oil and four of its compounds on rumen microbial fermentation. J. Dairy Sci. 88:4393-4404.

Cardozo, P. W., S. Calsamiglia, A. Ferret, and C. Kamel. 2006. Effects of alfalfa extract, anise, capsicum and a mixture of cinnamaldehyde and eugenol on ruminal fermentation and protein degradation in beef heifers fed a high concentrate diet. J. Anim. Sci. 84:2801-2808.

Chantalakhana, C. 2001. Contribution of Water Buffaloes in Rural Development. Proceeding Regional Workshop on Water Buffalo Development, Thongtarin Hotel, Surin, Thailand, 8-10 Februarry, 2001.

Chaves, A. V., K. Stanford, M. E. R. Dugan, L. L. Gibson, T. A. McAllister, F. Van Herk, and C. Benchaar. 2008a. Effects of cinnamaldehyde, garlic and juniper berry essential oils on rumen fermentation, blood metabolites, growth performance, and carcass characteristics of growing lambs. Livest. Sci. 117:215-224.

Chaves, A. V., M. L. He, W. Z. Yang, A. N. Hristov, T. A. McAllister, and C. Benchaar. 2008b. Effects of essential oils on proteolytic, deaminative and methanogenic activities of mixed ruminal bacteria. Can. J. Anim. Sci. 88:117-122.

Chen, X. B. and M. J. Gomes. 1995. Estimation of microbial protein supply to sheep and cattle based on urinary excretion of purine derivative - An overview of the technique details. Occasional publication 1992. International Feed Resources Unit, Rowett Research Institute, Aberdeen, UK.

Chen, X. B., D. J. Kyle, and E. R. Orskov. 1993. Measurement of allantoin in urine and plasma by high performance liquid chromatography with pre-column derivatization. J. Chromatogr. B. Biomed. Sci. Appl. 617:241-247.

Chen, X. L., J. K. Wang, Y. M. Wu, and J. X. Liu. 2008. Effects of chemical treatments of rice straw on rumen fermentation characteristics, fibrolytic enzyme activities and populations of liquid- and solid-associated ruminal microbes in vitro. Anim. Feed Sci. Technol. 141:1-14.

Crichton, N. 1999. Information point: Tukey's multiple Comparison test. Blackwell Science Ltd, J. Clinical Nursing, 8:299-304.

Crocker, C. L. 1967. Rapid determination of urea nitrogen in serum or plasma without deproteinization. Am. J. Med. Technol. 33:361-365.

Devendra, C. 1992. Nutrition of swamp buffalo. In: Buffalo Production, World Animal Science, C6. (Ed. N. M. Tulloh and J. H. G. Holmes). Elsevier. Tokyo.
Fadel-Elseed, A. M. A., J. Sekine, M. Hishinuma, and K. Hamana. 2003. Effects of ammonia, urea plus calcium hydroxide and animal urine treatments on chemical composition and in sacco degradability of rice straw. Asian-Aust. J. Anim. Sci. 16:368373.

Galyean, M. 1989. Laboratory procedure in animal nutrition research. Department of animal and range science. New Mexico State University, USA.

Giannenas, I., J. Skoufos, C. Giannakopoulos, M. Wiemann, O. Gortzi, S. Lalas, and I. Kyriazakis. 2011. Effect of essential oils on milk production, milk composition, and rumen microbiota in Chios dairy ewes. J. Dairy. Sci. 94:5569-5577.

Goto, M., Y. Yokoe, K. Takabe, S. Nishikawa, and O. Morita. 1993. Effects of gaseous ammonia on chemical and structural features of cell walls in spring barley straw. Anim. Feed Sci. Technol. 40:207-221.

Helander, I. M., H. Alakomi, K. Latva-Kala, T. Mattila-Sandholm, I. Pol, E. J. Smid, L. G. M. Gorris, and A. Wright. 1998. Characteritzation of the action of selected essential oil components on gram-negative bacteria. J. Agric. Food Chem. 46:3590-3595.

Hess, H. D., C. E. Lascano, and H. Flórez. 2000. Blood and milk urea nitrogen as a tool to monitor the protein nutrition of cattle under tropical conditions. Institute of Animal Sciences, Animal Nutrition, ETH, Zurich, Switzerland.

Hoover, W. H. and S. R. Stokes. 1991. Balancing carbohydrates and proteins for optimum rumen microbial yield. J. Dairy Sci. 74:3630-3644.

Hungate, R. E. 1969. A role tube method for cultivation of strict anaerobes. Method in mMicrobiology (Ed. J. R. Norris and D. W. Ribbons). New York, Academic. NY. 313.

Kebreab, E., G. D. Cruz, P. H. Hai, N. Anatassok, S. Polyorach, P. Beelen, and H. D. Rosa. 2012. Methane emission profile in dairy heifers feed rice straw. In Proc. The 1st International Conference on Animal Nutrition and Environment. Khon Kaen, Thailand.

Khejornsart, P., M. Wanapat, and P. Rowlinson. 2011. Diversity of anaerobic fungi and rumen fermentation characteristic in swamp buffalo and beef cattle fed on different diet. Livest. Sci. 139:230-236

Kongmun, P., M. Wanapat, P. Pakdee, C. Navanukraw, and Z. Yu. 2011. Manipulation of rumen fermentation and ecology of swamp buffalo by coconut oil and garlic powder supplementation. Livest. Sci. 135:84-92.

Kongmun, P., M. Wanapat, P. Pakdee, and C. Navanukraw. 2010. Effect of coconut oil and garlic powder on in vitro fermentation using gas production technique. Livest. Sci. 127:38-44.

Leng, R. A. 1993. The impact of livestock development on environmental change. FAO Corporate Documentary Repository, pp:1-14.

Liang, J. B., M. Matsumoto, and B. A. Young. 1994. Purine derivative excretion and rumen microbial yield in Malaysian cattle and swamp buffalo. Anim. Feed Sci. Technol. 47:189199.

Malecky, M., L. P. Broudiscou, and P. Schmidely. 2009. Effects of two levels of monoterpene blend on rumen fermentation, terpene and nutrient flows in the duodenum and milk 
production in dairy goats. Anim. Feed Sci. Technol. 154:24-35.

McInstosh, F. M., P. Williams, R. Losa, R. J. Wallace, D. A. Beever, and C. J. Newbold. 2003. Effect of essential oils on ruminal microorganisms and their protein metabolism. Appl. Environ. Microbiol. 69:5011-5014.

Mohammed, N., N. Ajisaka, Z. A. Lila, K. Mikuni, S. Kanda, and H. Itabashi. 2004. Effects of Japanese horseradish oil on methane production and ruminal fermentation in vitro and in steers. J. Anim. Sci. 82:1839-1846.

Moss, A. R., J. P. Jouan, and J. Ne wbold. 2000. Methane production by ruminants: its contribution to global warming. Ann. Zootech. 49:231-253.

Newbold, C. J., F. M. McInstosh, P. Williams, R. Losa, and J. Wallace. 2004. Effects of a specific blend of essential oils compounds on rumen fermentation. Anim. Feed Sci. Technol. 114:105-112.

Patra, A. K. 2011. Effects of essential oils on rumen fermentation, microbial ecology and ruminant production. Asian J. Anim. Vet. Adv. 6:416-428.

Patra, A. K., D. N. Kamra, and N. Agarwal. 2010. Effects of extracts of spices on rumen methanogenesis, enzyme activity and fermentation of feeds in vitro. J. Sci. Food Agric. 90:511520.

Perdok, H. and R. A. Leng. 1989. Rumen ammonia requirements for efficient digestion and intake of straw by cattle. In: The Roles of Protozoa and Fungi in ruminant Digestion (Ed. J. V. Nolan and R. A. Leng, Demeyer). Penambul Books, Armidale, Australia.

Preston, T. P. and R. A. Leng. 1987. Matching ruminant production systems with available resources in the tropics and sub-tropics. Penambul Books, Armidale, N.S.W. Australia.

Russell, J. B., H. J. Strobel, and G. Chen. 1988. Enrichment and isolation of a ruminal bacterium with a very high specific activity of ammonia production. Appl. Environ. Microbiol. 54:872-877.

Sallam, S. M. A., I. C. S Bueno, M. E. A. Nasser, and A. L. Abdalla. 2010. Effect of eucalyptus (Eucalyptus citriodora) fresh or residue leaves on methane emission in vitro. Ital. J. Anim. Sci. 9:e58.

Sallam, S. M. A., M. E. A. Nasser, R. C. Araujo, and A. L. Abdalla. 2009. Methane emission in vivo by sheep consuming diet with different levels of eucalyptus essential oil. In Proc. FAO/IAEA Int. Symp. On sustainable improvement of animal production and health, Vienna, Austria.

Samuel, M., S. Sagathewan, J. Thomas, and G. Mathen. 1997. An HPLC method for estimation of volatile fatty acids of ruminal fluid. Indian J. Anim. Sci. 67:805-807.

Santos, M. B., P. H. Robinson, P. Williams, and R. Losa. 2010. Effect of addition of an essential oil complex to the diet of lactating dairy cows on whole tract digestion of nutrients and productive performance. Anim. Feed Sci. Technol. 157:64-71.

SAS. 1998. SAS/STAT User's Guid 6. 12th ed. SAS Institue Inc., Cary, Nort Carolina.
Shibata, M., F. Terada, M. Kurihara, T. Nishida, and K. Iwasaki. 1993. Estimation of methane production in ruminants. Anim. Sci. Technol. 64:790-796.

Tatsouka, N., K. Hara, K. Mikuni, K. Hara, H. Hashimoto, and H. Itabashi. 2008. Effects of the essential oil cyclodextrin complexes on ruminal methane production in vitro. Anim. Sci. J. 79:68-75.

Tekippe, J. A., A. N. Hristov, K. S. Heyler, T. W. Cassidy, V. D. Zheljazkov, J. F. S. Ferreira, S. K. Karnati, and G. V. Varga. 2011. Rumen fermentation and production effects of Origanum vulgare L. leaves in lactating dairy cows. J. Dairy. Sci. 94:5065-5079.

Van Soest, P. J., J. B. Robertson, and B. A. Lewis. 1991. Methods of dietary fiber, neutral detergent fiber and non-starch carbohydrates in relation to animal nutrition. J. Dairy Sci. 74:3583-3597.

Wallace, R. J. 2004. Antimicrobial properties of plant secondary metabolites. Proc. Nutr. Soc. 63:621-629.

Wallace, R. J., N. R. McEwan, F. M. McIntosh, B. Teferedegne, and C. J. Newbold. 2002. Natural products as manipulators of rumen fermentation. Asian-Aust. J. Anim. Sci. 15:1458-1468.

Wanapa M., P. Khejornsart, P. Pakdee, and S. Wanapat. 2008. Effect of supplementation of garlic powder on rumen ecology and digestibility of nutrients in ruminants. J. Sci. Food Agric. 88:2231-2237.

Wanapat M. and O. Pimpa. 1999. Effect of ruminal ammonia nitrogen levels on ruminal fermentation, purine derivatives, digestibility and rice straw intake in swamp buffaloes. AsianAus. J. Anim. Sci. 12:904-907.

Wanapat, M. 1985. Improving rice straw qulity as ruminant feed by urea-treatment in Thailand, pp. 147-175. In: Relevance of crop Residues as Animal Feed in Developing Countries (Ed. M. Wanapat and C. Devendra). Funny Press: Bangkok.

Wanapat, M. 1990. Nutritional aspects of ruminant production in Southeast Asia with special reference to Thailand. Funny Press, Ltd., Bangkok, Thailand.

Wanapat, M., S. Polyorach, K. Boonnop, C. Mapato, and A. Cherdthong. 2009. Effects of treating rice straw with urea or urea and calcium hydroxide upon intake, digestibility, rumen fermentation and milk yield of dairy cows. Livest. Sci. 125:238-243

Wang C. J., S. P. Wang, and H. Zhou. 2009. Influences of flavomycin, ropadiar and saponin on nutrient digestibility, rumen fermentation and methane emission from sheep. Anim. Feed Sci. Technol. 148:157-166.

Yang, W. Z., B. N. Ametaj, C. Benchaar, M. L. He, and K. A. Beauchemin. 2010. Cinnamadehyde in feedlot cattle diets: Intake, growth performance, carcass characteristics and blood metabolites. J. Anim. Sci. 88:1082-1092.

Yang, W. Z., C. Benchaar, B. N. Ametaj, A. V. Chaves, M. L. He, and T. A. McAllister. 2007. Effects of garlic and juniper berry essential oils on ruminal fermentation and on the site and extent of digestion in lactating cows. J. Dairy Sci. 90:56715681 . 